Den humanitære situasjonen på Gaza er elendig etter to års blokade og isolasjon. Israels massive angrep ved årsskiftet 2008/9 forverret situasjonen ytterligere. Utsiktene til snarlig bedring er små. Et flertall i Gaza ønsker nasjonal samling og forhandlinger.

Åge Tiltnes er Midtøsten-forsker ved Fafo.

\title{
Resignasjon, men fortsatt forhandlingsvilje i Gaza
}


TEKST: Åge Tiltnes

GAZAS MANGFOLDIGE historie er spekket med slag, erobringer, ødeleggelser og lidelse, og strekker seg flere tusen år tilbake i tid. ${ }^{\mathrm{I}}$ Israels «beleiring» de siste to år og det militære angrepet i desember og januar representerte således ikke noe nytt. Denne artikkelen vil ikke handle om historien, heller ikke den nære, da denne forutsettes kjent. I stedet vil den kort beskrive de forholdene Gazas I,5 millioner innbyggere lever under, og utfordringene de står overfor. I noen grad vil palestinerne selv komme til orde gjennom statistikk og med observasjoner om egen situasjon og palestinsk politikk. Informasjonen er samlet inn av forskningsstiftelsen Fafo på Vestbredden og i Gaza både før og etter krigshandlingene sist vinter. Det dreier seg om rundt I50 kvalitative intervjuer og en spørreundersøkelse i februar/mars i år. ${ }^{2}$

\section{Bakteppet}

Problemene til palestinerne på Gaza-stripen springer ut av konflikten mellom palestinere og israelere. Da Israel ble etablert $\mathrm{i}$ I948, flyktet rundt 800 o०० palestinere som følge av krigshandlinger, massakrer og trusler. ${ }^{3}$ Landområdet ved Middelhavet på størrelse med Hamar kommune tok imot en firedel av flyktningene. I dag utgjør flyktningene og deres etterkommere tre firedeler av innbyggerne i Gaza.

Etter at Israel okkuperte Vestbredden og Gaza i I967, fant det gradvis sted en kolonisering av de to områdene, i strid med internasjonal folkerett. Israel trakk seg ut av Gaza i 2005, men bosettingspolitikken fortsetter på Vestbredden, der det per i dag bor nesten 300000 israelere. $^{4}$

Den palestinske økonomien var tidligere godt integrert i den israelske. Etter at Osloprosessen raknet har Israel bygget en «separasjonsmur» mot, og delvis på, Vestbredden. Det argumenteres for at denne er til vern mot palestinske selvmordsaksjoner, med henvisning til egne borgeres sikkerhet. 5 Videre har Israel etablert et omfattende system av militære kontroller og veisperringer. ${ }^{6}$ Slike hindre fantes også i Gaza inntil bosetterne forlot området. I tillegg har antallet palestinere som arbeider i Israel, og på bosettingene, falt dramatisk, noe som har vært med på å kvele den palestinske økonomien.?

Tidligere arbeidet titusener av Gazabeboere i Israel, som også utgjorde eksportmarkedet for Gazas landbruk. Forbruksvarer gikk motsatt vei. Israelske stengningsregimer har over tid undergravet økonomien. Israels bortimot totale isolering av Gaza-stripen siden sommeren 2007 har forverret situasjonen ytterligere. Jordbruksprodukter eksporteres ikke leng- 
er og så godt som all industri er nedlagt. På to år er fangsten av fisk redusert med nesten tre firedeler fordi Israel forbyr fiskeflåten å gå lenger ut enn tre nautiske mil. Resultatet er dramatisk arbeidsløshet og fattigdom. Gaza, som Vestbredden, har gått fra avhengighet av den israelske økonomien til bistandsavhengighet. ${ }^{8}$ Kun det aller nødvendigste av matvarer, oljederivater og medisin blir tidvis sluppet inn i Gaza etter press fra FN og verdensopinionen, mens et hundretall smuglertunneler mellom Gazas sørlige grense og Egypt sørger for begrenset import av andre varer, inkludert våpen. Blokaden av Gaza har gitt kraftig prisstigning i kombinasjon med redusert kjøpekraft, levekårsforvitring og nød.

\section{Ødeleggelser og blokkert gjenoppbygging}

Tjuetre dagers krig var over den I8. januar 2009 etter at de to krigførende partene hadde erklært ensidig våpenhvile. Israel hadde gjennomført svært omfattende luftangrep supplert av to ukers bakkeoffensiv med den hensikt å stanse rakettbeskytning mot Sderot og andre sivile mål ved å knuse den palestinske islamske motstandsbevegelsen Hamas. ${ }^{9}$ Hamas, som tok kontroll over Gaza med makt sommeren 2007, hadde nylig gjenopptatt rakettbeskytningen etter seks måneders våpenhvile (tahdia), fordi Israel ikke hadde åpnet grenseovergangene. Da krigen var over hadde ingen nådd målene sine: Hamas var militært svekket, men satt trygt i Gaza og var fortsatt i stand til å avfyre raketter mot Israel, mens Israel beholdt jerngrepet om Gazastripen. $^{\text {. }}$

Krigen resulterte i rundt I400 døde og 5400 sårede palestinere. Et flertall av de drepte deltok ikke i kampene. ${ }^{\text {II }}$ Men krigføringen berørte enormt mange flere:
Bare 38 prosent av alle Gaza-familier bor i et nabolag uten materielle skader. Av alle nabolag har 62 prosent skade på privatboliger, mens henholdsvis 27 prosent, I7 prosent og 9 prosent av nabolagene har en eller flere ødelagte moskeer, skolebygg og helseinstitusjoner. ${ }^{\text {I2 }}$

Tre av ti familier flyktet fra sine hjem, og mange familier mer enn én gang. 3 prosent av disse (I prosent av alle familier) var ute av stand til å vende hjem etter krigen fordi boligene var lagt i grus eller ubeboelige. I alt fikk 27 prosent av Gazas boliger mindre skader, 23 prosent fikk mer omfattende ødeleggelser som kunne repareres, mens I prosent av boligmassen ikke kunne føres tilbake til opprinnelig stand. Knuste glassruter var den vanligste skadetypen (84 prosent av alle skadde boliger), dernest fulgte ødelagte tak (I3 prosent) og vegger (I2 prosent), ødelagt vannforsyning (9 prosent) og kloakksystem (2 prosent). En femdel av alle boligene på Gaza hadde behov for oppgradering til en prislapp på mellom ıooo og 5000 shekel, mens en litt større andel behøvde utbedring som eierne anslo til mer enn 5000 shekel (rundt 7800 norske kroner). ${ }^{\text {I3 }}$ Dette er ikke avskrekkende summer, men når offentlig ansatte lærere og sykepleiere med ti års erfaring har en månedslønn på rundt 2500 shekel er utbedring av skader vanskelig, eller umulig, for svært mange. Det faktum at så mange ble rammet, betyr også at tradisjonelle spleiselag der nær familie går sammen om større økonomiske løft blir en mindre farbar vei enn under normale omstendigheter.

Seks uker etter at krigshandlingene stanset, hadde man startet reparasjon av Io

FOTO: ARTINTIFADA.WORDPRESS.COM 


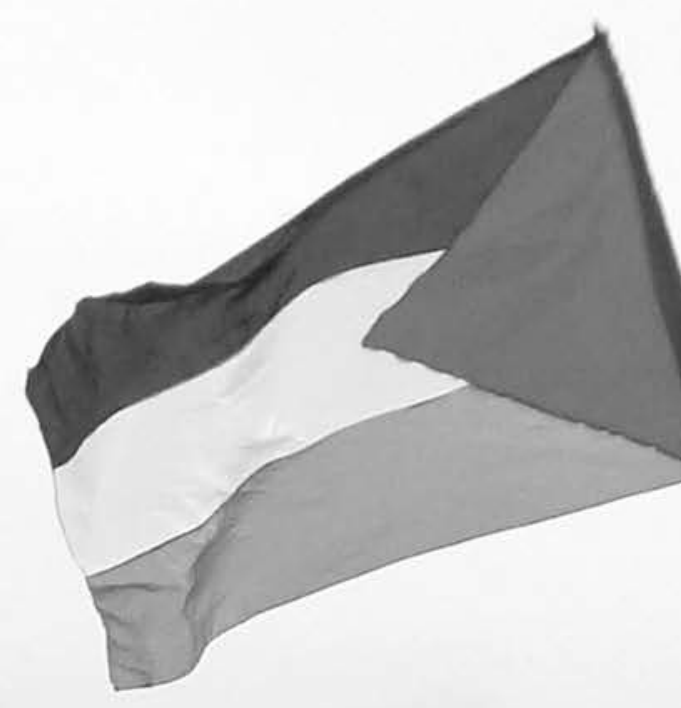

$\log _{4} \mathrm{C}$

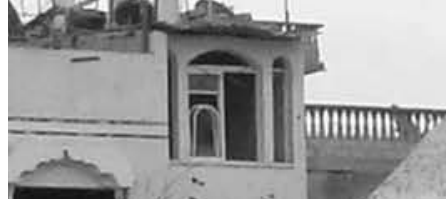

\section{반다.}

F.

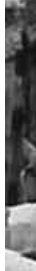

6
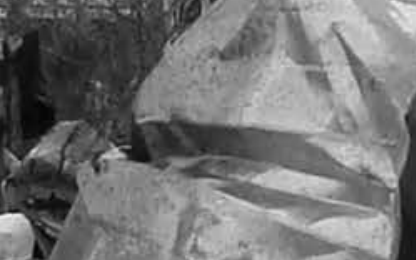

$\rightarrow$

isting

ist?

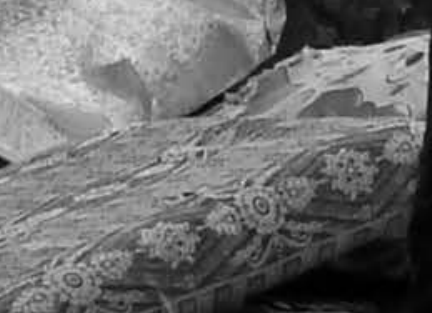

$3(0,5)=-1$
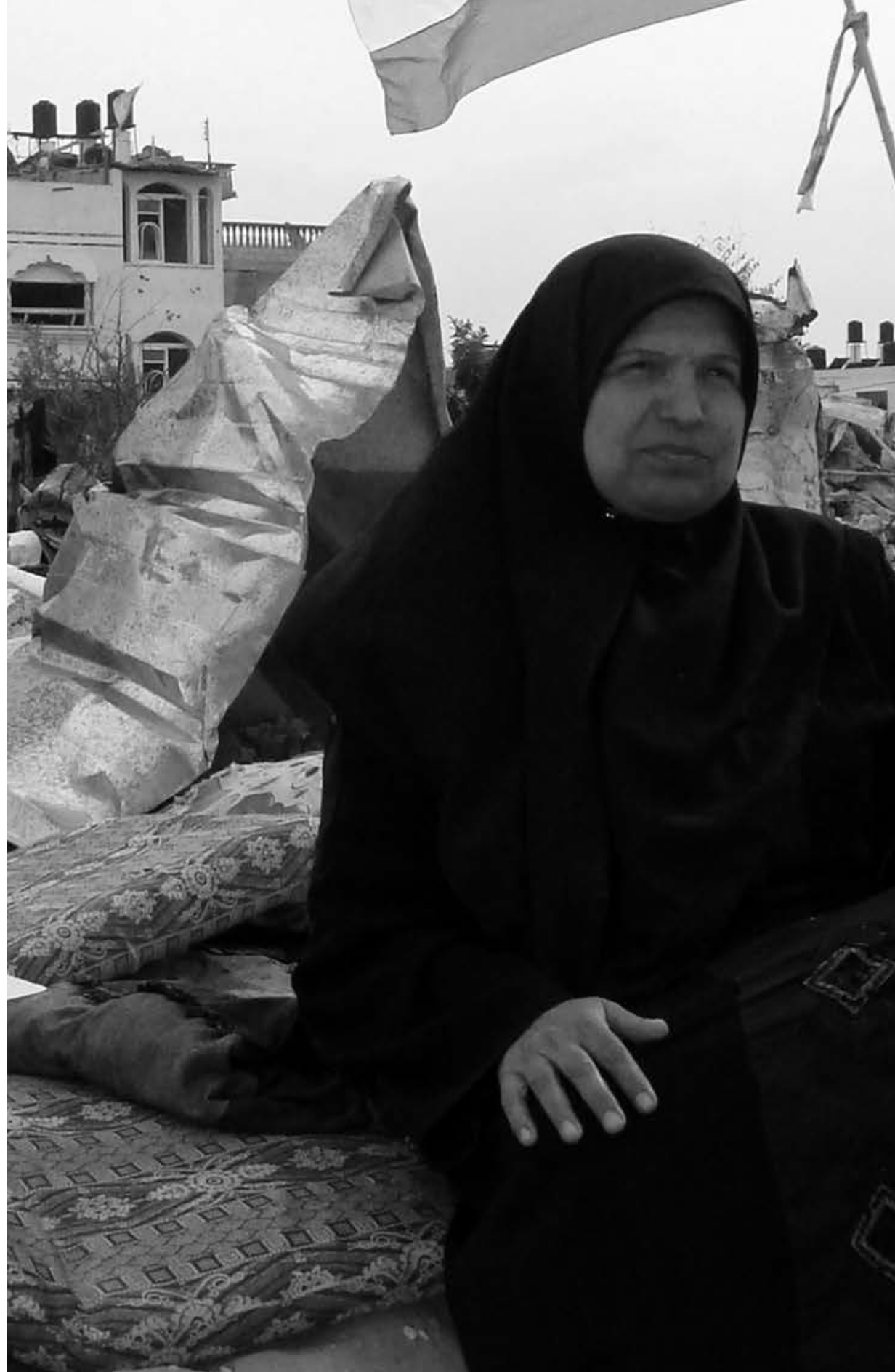

tor
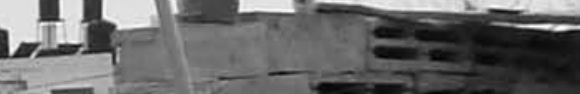

$r^{2}-2 x-2=0$

1) $15-=$

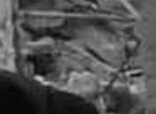
Ex -9.11
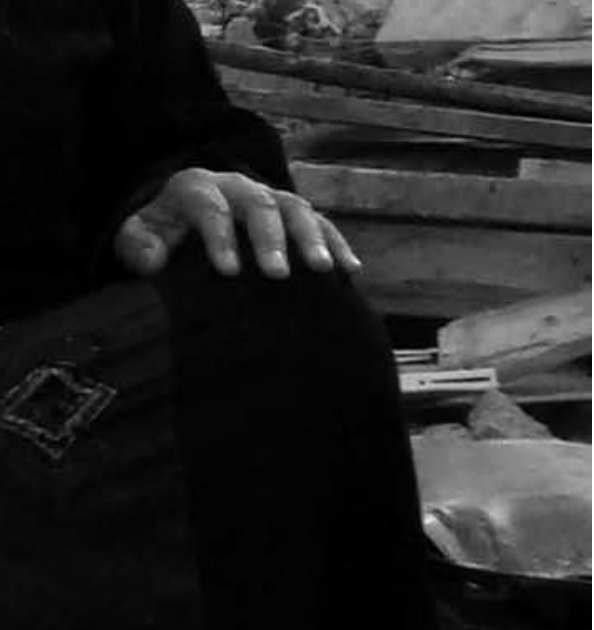
prosent av de skadde privatboligene. To av tre huseiere med ødelagt bolig hadde ingen plan for utbedring av skade eller gjenoppbygging grunnet pengemangel og/eller fravær av byggematerialer. Situasjonen var den samme seks måneder senere: Ifølge

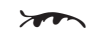

Den palestinske befolkningen er blitt mer usikker på om bruk av vold mot Israel er riktig og klokt.

FN sto da så godt som alle de over 6000 sønderbombete og hardest skadde boligene urørt grunnet Israels importforbud av

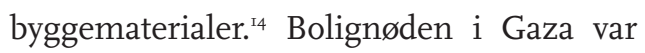
betydelig allerede før krigen på grunn av høy befolkningsvekst og ikke minst fordi Israel siden starten av den andre intifadaen hadde rasert rundt 4600 privatboliger og skadet 3000 til. ${ }^{15}$

\section{Psykisk terror}

I samtaler med i6 Gaza-familier fire uker etter krigshandlingene, framholdt flere informanter at Hamas ikke ble spesielt hardt rammet av krigen. ${ }^{\mathrm{I} 6}$ De beskrev bombingen som vilkårlig, noe som skapte frykt og en følelse av psykisk terror. Utryggheten ble eksemplifisert gjennom historier om hvordan israelske droner kontinuerlig fløy over Gaza og ofte skjøt mot folk, det være seg barn som lekte på hustak, ungdom som var ute for å handle eller gravide på vei til sykehus for å føde. Folk følte at hele Gaza-stripen var utsatt for beskytning. Dette var en viktig grunn til at «bare» 30 prosent flyktet; de hadde ingen steder å flykte til. Under bakkeinvasjonen erfarte mange at de israelske styrkene skjøt mot hus når det ble observert skygger $\mathrm{i}$ vinduene. Folk hadde gjemt seg i leilighetene sine i håp om ikke å bli truffet av granater eller håndvåpen. De to siste dagene av krigen ble opplevd som spesielt nervepirrende, og informantene beskrev en redsel de ikke hadde kjent maken til tidligere.

Seks uker etter krigen var Gazas befolkning fortsatt hardt preget av krigen. Tall fra Fafos spørreundersøkelse i mars viser at mange hadde symptomer på traumer og psykisk helsesvikt som hadde oppstått med krigen: ıo prosent led av søvnløshet; I5 prosent av barn i alderen 5-I4 var blitt sengevætere, og 20 prosent av barn i samme aldersgruppe hadde ifølge foreldrene fått konsentrasjonsproblemer. Andre indikasjoner på psykisk lidelse i den voksne befolkningen: 32 prosent hadde ofte en følelse av at krigen fortsatt pågikk, I 6 prosent var ofte plaget av mareritt, I8 prosent hadde ofte konsentrasjonsproblemer og like mange følte ofte ukontrollerbart sinne. $^{27}$

Likevel, på tross av et høyt antall døde og skadde, mange med midlertidige eller varige psykiske arr, og til tross for at mange trodde de ville komme til å måtte gjennomleve det samme igjen, var det ikke helse eller sikkerhet som toppet listen over saksforhold som opptok eller bekymret folk mest selv kort tid etter krigen. På toppen tronet den økonomiske og politiske situasjonen.

\section{Fattigdom}

86 prosent av de spurte sa de var svært eller ganske bekymret for den økonomiske situasjonen i Gaza. I tillegg svarte 64 prosent at de var svært eller ganske bekymret for situasjonen på arbeidsmarkedet. Dette reflekterte selvsagt den ødelagte økonomi- 
en. I mars i år var én av fire familier i Gaza uten noen form for inntekt; én av ti familier rapporterte at deres viktigste inntektskilde var støtte fra UNRWA, Hamas-regjeringen, selvstyremyndigheten eller en frivillig organisasjon. Nesten like mange fikk en håndsrekning fra slektninger, og kun drøyt halvparten av familiene hadde lønnsarbeid som viktigste inntekstkilde (I/3 fra privat sektor og $2 / 3$ fra offentlig sektor). Ifølge det palestinske statistiske byrået sto I40 000 personer som ønsket å arbeide uten jobb. ${ }^{18}$

To av tre familier oppga til Fafo at privatøkonomien hadde forverret seg de siste seks månedene. Bare tre av ti familier mente de ville være $\mathrm{i}$ stand til å dekke grunnleggende behov i nær framtid. 6o prosent svarte at de ville være ute av stand til å dekke en uforutsett utgift på ı०o० shekel, noe som er en dobling fra en spørreundersøkelse ett år tidligere. ${ }^{\text {I9 }}$ For rundt én av fem hadde situasjonen «alltid» vært vanskelig, rundt én av tre mente de hadde hatt det så vanskelig siden begynnelsen av den andre intifadaen, halvparten fortalte at deres økonomiske situasjon hadde vært så dårlig siden blokaden av Gaza ble innført i 2007 , mens bare 3 prosent la skylden for den håpløse situasjonen på krigen noen uker i forveien.

Levekårene i Gaza er blitt gradvis verre de siste årene. FN og Verdensbanken slår fast at flere er blitt rammet av fattigdom, og at fattigdommen er dypere enn før. Tall så høye som 70 og 80 prosent er blitt rapportert. $^{20}$

\section{Usikkerhet om vold som virkemiddel}

Selv om palestinere flest forklarer krigsutbruddet med israelsk aggresjon, mente 40 prosent (tre av fire Fatah-velgere; en av sju
Hamas-velgere) at Hamas i større eller mindre grad også kunne klandres. Halvparten (to av fem Fatah-velgere; tre av fem Hamas-velgere) mente at «den palestinske saken» hadde tjent på krigen. En litt større andel, 55 prosent (tre av fire Fatah-velgere; tre av ti Hamas-velgere), mente at rakettbeskytning av israelske mål burde opphøre, en økning fra 39 prosent i 2007 og 42 prosent i 2008. ${ }^{21}$ Dette antyder at den palestinske befolkningen er blitt mer usikker på om bruk av vold mot Israel er riktig og klokt.

Forut for krigen var oppslutningen om væpnet kamp forholdsvis høy i den palestinske befolkningen. I 2005 mente to tredeler av de spurte i en meningsmåling i regi av Fafo at militære operasjoner mot Israel var legitime svar på den politiske situasjonen. Halvparten svarte til og med at selvmordsangrep var nødvendig for å framtvinge israelske innrømmelser. ${ }^{22}$ I 2006 hadde prosentandelen som mente at militære operasjoner mot Israel var et legitimt virkemiddel økt til $84 .{ }^{23}$ På det tidspunktet, som nå, var det små forskjeller i oppfatningen mellom Vestbredden og Gaza. Flere titalls intervjuer på Vestbredden høsten 2008 viste at brede lag av den palestinske befolkningen uavhengig av partipolitisk tilhørighet aksepterte væpnet motstand. ${ }^{24}$ En overlærer ved en UNRWAskole sa for eksempel følgende til en kollega av meg:

Et vanskelig spørsmål for palestinere akkurat nå er hva som skal bli vårt neste strategiske skritt. På gata finner folk svaret $i$ mer motstandskamp. Folk ønsker å la israelerne føle og betale kostnaden ved okkupasjonen. For meg er dette veldig vanskelig, spesielt etter en lang periode med fredsforhandlinger. Selv Fatah- 
folk ber om mer motstandskamp nå som de opplever at veien til fred er stengt. Det eneste svaret jeg ser er dessverre mer motstand. Jeg ønsker slett ikke et Hamas-regime, men når forhandlingene ikke virker, hva $i$ all verden skal vi gjøre? Det virker som om verden dytter vårt regime $i$ en retning vi ikke ønsker. Dette gjør meg virkelig pessimistisk.

Imidlertid etterlot intervjuer på Vestbredden og Gaza-stripen etter Israels voldsomme angrep sist vinter seg et inntrykk av at palestinerne hadde blitt mer skeptiske til væpnet kamp, noe som også gjenspeiles i statistikken om økt motstand mot rakettbeskytning. «Vanlige folk» syntes kostnadene var altfor høye.

\section{Sterkt ønske om nasjonal forsoning}

Samtidig uttrykte et flertall på 72 prosent (fire av fem Fatah-velgere; tre av fem Hamas-velgere) et ønske om fredsforhandlinger med Israel dersom Hamas og president Abbas samarbeidet. Forhandlinger mellom henholdsvis Abbas og Israel eller Hamas og Israel fikk 20 prosentpoeng lavere oppslutning. Dette er et av flere uttrykk for den fortvilelse folk flest følte over den opprivende striden mellom Fatah og Hamas, Vestbredden og Gaza, og at de ønsket palestinsk forsoning.

I mars fryktet 53 prosent av Gazas innbyggere at konflikten mellom de to største politiske partiene igjen kunne lede til væpnete kamper i Gaza, og 46 prosent mente det samme kunne skje på Vestbredden. To av fem mente at krigen hadde ført Vestbredden og Gaza lenger fra hverandre. Ni av ti avviste likevel økt uavhengighet mellom de to områdene dersom konflikten mellom Fatah og Hamas ikke skulle bli bilagt.
Bare halvparten av de spurte betraktet Abbas som Palestinas legitime president, og 86 prosent sa at det var på tide at Fatah skiftet ut sine toppledere. Men 84 prosent avviste tanken om å avvikle selvstyremyndigheten som svar på dagens politiske utfordringer. Folk flest mente altså at det palestinske statsbyggingsprosjektet burde bestå. Halvparten av Gazas innbyggere sa de fryktet at den palestinske frigjøringsorganisasjonen PLO kunne komme til å kollapse, og fire av fem mente Hamas burde bli medlem av PLO. Som med selvstyremyndighetene, anså man at PLO måtte styrkes og revitaliseres. ${ }^{25}$

I mars mente 36 prosent at regjeringen Haniyeh var Palestinas legitime regjering, mens 3I prosent holdt en knapp på regjeringen Fayyad. I2 prosent mente begge regjeringene var legitime, mens 22 prosent avviste dem begge. Dersom det var valg i mars ville Fatah og Hamas fått omtrent samme andel av stemmene (29 prosent og 26 prosent), men «hjemmsitterpartiet» ville vært like stort (28 prosent). ${ }^{26}$ Folks misnøye med «egne» partier er forholdsvis stor: Bare 70 prosent av dem som stemte Fatah ved valget i 2006 sa de ville gjort det samme igjen. Hamas opplever enda større velgerflukt ved at kun 62 prosent av de som stemte på partiet den gang bekreftet at de ville gjort det samme ved et nytt valg. Hele 95 prosent uttrykte imidlertid at Hamas og Fatah burde starte forhandlinger om en koalisjonsregjering.

Befolkningen i Gaza var altså i villrede om valg av strategi og taktikk for å få opphevet blokaden av Gaza og å etablere en palestinsk stat, men var enig om at samhold var en betingelse for å vinne fram. Samtaler Fafo hadde med palestinere i Gaza og på Vestbredden etter krigen tydet 
på større forventninger om nasjonal forsoning og samlingsregjering enn på lenge.

\section{Mer av det samme}

Folks håp om forsoning er imidlertid ikke blitt innfridd. Til tross for enkelte positive signaler, har gjentatte forhandlingsrunder mellom Fatah og Hamas i skrivende stund ikke ført fram. I stedet har de to partiene og myndighetene til folks vemmelse og frustrasjon fortsatt å begå menneskerettighetsbrudd mot hverandres aktivister og tilhengere. ${ }^{27}$

I5 prosent av de spurte i Fafos spørreundersøkelse i mars mente at Israels blokade ville bli hevet i nær framtid. Disse tok feil. Blokaden er like konsekvent som før krigen. Bare det aller nødvendigste kommer inn i Gaza, og, som nevnt ovenfor, gjenoppbyggingen er knapt kommet i gang. Isolasjonspolitikken som FN har kalt «kollektiv avstraffelse» og «systematisk ødeleggelse» av folks levekår fortsetter. ${ }^{28}$

Seks uker etter krigen tvilte de aller fleste i Gaza på at våpenhvilen ville vare. Tiden har vist at de hadde rett: Palestinerne har avfyrt raketter mot Israel og Israel har bombet Gaza. Israelske droner flyr over Gaza som en påminnelse om krigen. Frykten opprettholdes, helingsprosessen forsenes, og hatet mot Israel øker. Ikke de beste forutsetninger for fredelig sameksistens med Israel, som tross alt er det flertallet av Gazas befolkning ønsker seg.

\section{Forhandlinger?}

Situasjonen er fastlåst, men en vei til økt trygghet for både Gazas palestinere og israelske statsborgere kan finnes dersom palestinerne får ledere av et kaliber de fortjener og dersom den israelske regjeringen faktisk ønsker, eller av USA blir tvunget til, reelle forhandlinger med palestinerne.

Fafos spørreundersøkelse i mars fikk følgende resultat da vi spurte hvilket utfall folk håpet på i konflikten om Palestina/Israel: To stater (37 prosent), én islamsk stat (34 prosent), én demokratisk stat med like rettigheter til alle ( $\mathrm{I} 6$ prosent), tre stater ( 2 prosent), vet ikke (II prosent). ${ }^{29}$ Umiddelbart kan det være vanskelig å se at dette er forenlig med fredsforhandlinger, som et flertall på over 70 prosent av palestinerne sier de ønsker. For

\section{mom \\ Bare halvparten av de spurte betraktet Abbas som Palestinas rett- messige president.}

halvparten av Gaza-beboerne kan da ikke for alvor mene at den israelske regjeringen skal forhandle vekk staten Israel til fordel for én stat i hele Palestina/Israel, den være seg islamsk eller sekulær? Prosentsatsene over er kun forståelig dersom en legger til grunn at det er snakk om respondentenes oppfatning om en framtidig, endelig løsning.

I samsvar med resultatene fra spørreundersøkelsen har Fafos intervjuer på Vestbredden og i Gaza vist at i takt med en voksende erkjennelse av Oslo-prosessens kollaps har håpet om en snarlig tostatsløsning forvitret og folks tidshorisont for en løsning er blitt lengre. De siste årene har også én stat som løsning blitt livlig debattert og, ifølge Fafos intervjuer, fått gradvis større tilslutning. Nostalgi knyttet til de mange nakba-markeringene i 2008 virker å ha bidratt til dette. 
Likevel, våre intervjuer antyder at svært mange av de 50 prosent som, ifølge målingen i mars, imøteser en énstatsløsning er villig til å akseptere en tostatsløsning på veien dit. De betrakter én stat som den endelige utgangen på dramaet tre, fire eller enda flere generasjoner fram i tid. En slik oppfatning deles også av palestinere som definerer seg som Hamas-tilhengere og, ser det ut til, representerer et syn som er godt representert i Hamas' ledelse. Analyser av Hamas konkluderer i hvert fall med at organisasjonen har moderert seg de senere år og de facto har anerkjent den israelske staten, mot at det etableres en palestinsk stat på Vestbredden og Gaza-stripen langs I967-grensene..$^{3 \circ}$ I praksis innebærer det at Hamas nærmer seg det standpunktet Fatah og PLO inntok i I988, og burde i prinsippet gi rom for framgang $i$ forhandlinger mellom Abbas og Haniyeh og åpne for at Hamas trer inn i PLO. En aller annen form for forståelse mellom Fatah og Hamas er nødvendig for framgang i forhandlinger mellom palestinerne og Israel og dermed for levekårsforbedring på Gaza-stripen gjennom oppheving av blokaden.

\section{$\cdot f \cdot$}

I Butt, Gerald: «Life at the Crossroads», Nicosia/ Essex: Rimal/ Scorpion Cavendish, I995.

2 Akram Atallah, Hani Eldada, Mona Christophersen, Laura Mitchell og forfatteren har det siste året intervjuet palestinere med variert sosioøkonomisk bakgrunn og politisk ståsted om levekår, palestinsk politikk og den israelskpalestinske konflikten. Statistikken er basert på svar fra ca. 2000 hushold på Gaza-stripen. Sammen med statistikk basert på svar fra 1500 hushold på Vestbredden og øvrig informasjon om surveyene, er den tilgjengelig fra http://www.fafo.no/ais/middeast/opt/index.htm. Materialet fra det kvalitative arbeidet er til nå ikke publisert, men to rapporter, en med ved vekt på levekår og en annen om politiske holdninger, er under utarbeidelse. Takk til Utenriksdepartementet som finansierer arbeidet.

3 Butenschøn, Nils A.: «Midtøsten: Imperiefall, statsutvikling, kriger», Oslo: Universitetsforlaget, 2008; Farsoun, Samih K.: «Palestine and the Palestinians", Boulder: Westview Press, 1997; Masalha, Nur: «The Politics of
Denial: Israel and the Palestinian Refugee Problem», London: Pluto Press, 2003; Morris, Benny: «The Birth of the Palestinian Refugee Problem, I947-1949”, Cambridge: Cambridge University Press, I987; Pappe, Ilan: «The Ethnic Cleansing of Palestine», Oxford: Oneworld, 2007.

4 I tillegg bor det nærmere 200000 israelere i bosettinger i okkupert Øst-Jerusalem, ifølge tall for utgangen av 2008 fra det israelske statistiske byrået. For informasjon om israelske bosettinger og bosettingspolitikk, se B'tselem (http://www.btselem.org/English/) og Foundation for Middle East Peace (http://www.fmep.org/).

5 Dolphin, Ray: «The West Bank Wall: Unmaking Palestine», London: Pluto Press, 2006; Ingdal, Nora og Simonsen, Anne Hege: «Mur: Delt landskap i Israel og Palestina», Oslo: Cappelen, 2005; OCHA: "Five Years after the International Court of Justice Advisory Opinion: A Summary of the Humanitarian Impact of the Barrier", juli 2009 (http://unispal.un.org/pdfs/BarrierRpt_0709.pdf).

6 Den israelske hæren foretar jevnlig raid for å arrestere palestinere de mener er involvert i terrorvirksomhet. Israels brudd på menneskerettighetene i De okkuperte områdene er godt dokumentert. Se for eksempel hjemmesidene til menneskerettighetsorganisasjonene Al-Haq (palestinsk; http://www.alhaq.org/index.php) og B'tselem (israelsk; http://www.btselem.org/English/index.asp).

7 Farsakh, Leila: "The political economy of Israeli occupation: what is colonial about it?", i The MIT Electronic Journal of Middle East Studies, vår, 2008, s. 4I-58; Roy, Sara: «Failing Peace: Gaza and the Palestinian-Israeli Conflict», London/Ann Arbor, Michigan: Pluto Press, 2007.

8 Le More, Anne: «International Assistance to the Palestinians after Oslo: Political Guilt, Wasted Money», New York: Routledge, 2008; World Bank: "Palestinian Economic Prospects: Gaza Recovery and West Bank Revival”, Economic Monitoring Report to the Ad Hoc Liaison Committee, 8. juni 2009 (http://siteresources.worldbank.org/ INTWESTBANKGAZA/Resources/AHLCJuneogReport final.pdf).

9 Om Hamas, se f.eks. Hroub, Khaled: «Hamas: A Beginner's Guide», London: Pluto Press, 2006; Gunning, Jeroen: «Hamas in Politics: Democracy, Religion, Violence», New York: Columbia University Press, 2oo8; og Jensen, Michael Irving: «The political Ideology of Hamas: A Grassroots Perspective», London: I.B. Tauris, 2009.

Io International Crisis Group (ICG): “Gaza's Unfinished Business", Middle East Report No. 85, 23. april 2009 (http://www.crisisgroup.org/home/index.cfm?id=607I).

II Forskjellige kilder (det palestinske helsedepartementet, Palestinian Center for Human Rights, B'tselem, OCHA) oppgir litt ulike tall. Palestinerne drepte ni israelere under krigen, hvorav fem i Gaza og fire etter rakettbeskytning av det sørlige Israel.

I2 Artikkelens beskrivelse av krigens konsekvenser bygger først og fremst på Fafo \& UNFPA: "Living conditions in the Gaza Strip during and after Israel's military campaign in the winter of 2008/2009: Evidence from interviews with 2,000 households", Fafo-paper 2009:I8, Jerusalem og Oslo, 2009 (tilgjengelig fra http://www.fafo.no/ais/ middeast/opt/gazasrvog/index.htm). Det aller meste av statistikken om levekår og husholdsøkonomi stammer også derfra. 
I3 Iooo shekel tilsvarer 260 USD eller I560 norske kroner.

I4 OCHA: "Locked in: The humanitarian impact of two years of blockade on the Gaza Strip", Øst-Jerusalem, august 2009 (http://www.ochaopt.org/documents/Ocha_opt_ Gaza_impact_of_two_years_of_blockade_August_2009 _english.pdf).

I5 Al Mezan Center for Human Rights, Gaza (http:// www.mezan.org/en/messege.php?view=homesen).

I6 Intervjuene ble foretatt av Mona Christophersen II-I6. februar. De fant sted i og nær Gaza by (Rimal, Salah El Din-området, Tel Al Hawa, Zeitoun og Beach camp) samt i Beit Lahia, nord for byen. Noen av stedene var sterkt berørt av krigen med mange ødelagte hus og synlige spor etter bombing og bakkeinvasjon, mens andre hadde kun mindre fysiske skader. Intervjuobjektene var av begge kjønn og i alle aldre, fattige og rike, flyktninger og ikkeflyktninger, og representerte hele det politiske spektrum. Ofte var medlemmer av storfamilien og naboer til stede.

I7 I tillegg til rapporten til UNFPA \& Fafo (se note I2), inneholder følgende $\mathrm{FN}$-utgivelser interessant informasjon om Gaza-befolkningens psykososiale situasjon kort tid etter krigen: UNDP: "Inside Gaza: Attitudes and perception of the Gaza Strip residents in the aftermath of the Israeli military operations", UNDP/PAPP 2009 (http://unispal.un.org/pdfs/UNDP_InsideGaza.pdf); UNFPA: "Gaza Crisis: Psycho-social Consequence for Women, Youth and Men: Executive Summary" (hele rapporten foreligger på arabisk), 27. april, 2009; og UNIFEM: "Voicing the needs of women and men in Gaza: Beyond the aftermath of the 23 day Israeli military operations", UNIFEM and the UN Gender Task Force, 2009 (http://www.unifem.org/attachments/products /UN_Gender_Needs_Survey_for_the_Gaza_Strip.pdf).

I8 OCHA: "Locked in"; se note I4.

I9 Fafo: "Surveying Palestinian opinions, March 2008", tabell 4.9, tilgjengelig fra http://www.fafo.no/ais/mid deast/opt/opinionpolls/poll2008.html.

20 UNDP: "Poverty in the occupied Palestinian territory 2007", Development Times, No. I, juli 2007 (http://www.undp.ps/en/newsroom/publications/pdf/ other/dtpov.pdf); OCHA: OCHA-oPt Socio-Economic Fact Sheet, april 2008 (http://www.ochaopt.org/doc uments/OCHA_oPt_SocioEconomics_Fact_Sheet_April _2008_English.pdf); UNRWA: "Poverty in the occupied Palestinian territory 2007", Briefing paper, May 2009 (http://www.un.org/unrwa/publications/pubso8/opt_ poverty2007_mayo9.pdf); World Bank: "Palestinian Economic Prospects: Gaza Recovery and West Bank Revival", Economic Monitoring Report to the Ad Hoc Liaison Committee, 8. juni 2009 (http://siteresources.world bank.org/INTWESTBANKGAZA/Resources/AHLC JuneogReportfinal.pdf).

2I Det er verdt å merke seg at de aller fleste synspunkter som artikkelen tillegger palestinere i Gaza også gjenspeiler oppfatningene på Vestbredden. Spørreundersøkelsene til Fafo, også den siste fra februar/mars i år, viser at meningene til palestinere i de to områdene er ganske like, på de fleste områder. For eksempel var også 55 prosent av Vestbredden-palestinerne positive til å stanse rakettbeskytning mot mål i Israel i mars i år.
22 Hasselknippe, Gro: "Palestinian Opinions on Peace and Conflict, Internal Affairs and Parliament Elections 2006", Oslo: Fafo-paper 2006:09, tabell 2 og 3 (http://www. fafo.no/pub/rapp/797/797.pdf).

23 Fafo: "Surveying Palestinian Opinons, December 2006", tabell 3.43, tilgjengelig fra http://www.fafo.no/ais/mid deast/opt/opinionpolls/index.htm.

24 Se note 2.

25 PLO er forøvrig den palestinske institusjonen som nyter størst tillit blant folk (sammenliknet med regieringene til Fayyad og Haniyeh, de folkevalgte, sikkerhetsstyrkene til de to regjeringene, politiske partier, og palestinske frivillige organisasjoner).

26 Dette utgjorde en framgang for Hamas og tilbakegang for Fatah sammenliknet med Fafos meningsmåling ett år tidligere. Fafo: "Surveying Palestinian opinion, March 2008 ", tabell 6.68 og 6.69, tilgjengelig fra http:// www.fafo.no/ais/middeast/opt/opinionpolls/poll2008 .html. På Vestbredden sa 27 prosent sa de ville stemt Fatah, mens ig prosent ville stemt Hamas.

27 Se f.eks. rapportene fra Palestinian Center for Human Rights i Gaza (http://www.pchrgaza.org/) og Independent Commission for Human Rights i Ramallah (http:// www.ichr.ps/index.php).

28 Charbonneau, Louis: "Collective punishment of Gaza is wrong - U.N.", Reuters, I8. januar, 2008 (http://www.reuters.com/article/latestCrisis/idUSN I8343083); OCHA: "Locked in: The humanitarian impact of two years of blockade on the Gaza Strip", ØstJerusalem, august 2009, s. 5 .

29 På Vestbredden uttrykte noe flere (22 prosent) seg som tilhengere av det gamle PLO-standpunktet om én sekulær stat, mens oppslutningen om en islamsk stat og to stater var noe lavere (henholdsvis $32 \%$ og $34 \%$ ).

30 Hovdenak, Are: "Kan Hamas presses til moderasjon?" i Babylon, nr. 2, 2008, s. 50-6I og "Hamas in transition: the failure of sanctions", i Democratization, vol. I6, nr. I. 2009, s. 59-80; Scham, Paul og Abu-Irshaid, Osama: "Hamas: Ideological Rigidity and Political Flexibility", Washington: United States Institute of Peace, Special Report 224, juni 2009 (http://www.usip.org/files/ resources/Special\%20Report\%20224_Hamas.pdf); Baroud, Ramzy: “Hamas' political impasse”, Ma'an News Agency, 4. juli, 2009 (http://www.maannews.net/eng/ ViewDetails.aspx? ID=2II670). 